Doi: HTTPS://DOI.ORG/10.23910/IJBSM/2017.8.2.1800

\title{
Soil Organic Carbon Pools as Affected by Land Use Types in Hilly Ecosystems of Manipur
}

\author{
Thounaojam Thomas Meetei ${ }^{1}$, Manik Chandra Kundu ${ }^{1 *}$, Yumnam Bijilaxmi Devi and Nirmala Kumari ${ }^{1}$
}

${ }^{1}$ Dept. of Soil Science and Agricultural Chemistry, Institute of Agriculture, Visva-Bharati, Sriniketan, W.B. (731 236), India

${ }^{2}$ Dept. of Soil Science, Assam Agricultural University, Jorhat, Assam (785 013), India

Corresponding Author

Manik Chandra Kundu

e-mail: mckundu@gmail.com

\author{
Article History \\ Manuscript No. AR1800 \\ Received in $26^{\text {th }}$ February, 2017 \\ Received in revised form 23 ${ }^{\text {rd }}$ March, 2017 \\ Accepted in final form $6^{\text {th }}$ April, 2017
}

\begin{abstract}
Soil organic carbon (SOC) stock is a function of climatic conditions, vegetation and soil characteristics. SOC pool is comprised of labile and recalcitrant pools with varying residence time. Labile pool of SOC is very important as it influences soil quality, soil productivity and also it has an impact on global warming. Surface soil samples were collected on February-March, 2015 from four predominant land-use systems viz., forest, grassland, cultivated (rice) land (>10 years) and jhum land ( 2 years) of the humid subtropical Senapati district of Manipur, India to assess the impact of these land-uses on various pools of SOC viz., total organic carbon (TOC), oxidizable organic carbon, very labile, labile, less labile and recalcitrant carbon fractions. The SOC content of forest land recorded highest $\left(23.68 \mathrm{~g} \mathrm{~kg}^{-1}\right)$ and that of cultivated land recorded lowest $\left(13.13 \mathrm{~g} \mathrm{~kg}^{-1}\right)$. The SOC stock was highest in forest land $\left(63.47 \mathrm{mg} \mathrm{ha}^{-1}\right)$ which was however statistically at par with grassland $\left(60.33 \mathrm{mg} \mathrm{ha}^{-1}\right)$ and that cultivated land was lowest $\left(38.69 \mathrm{mg} \mathrm{ha}^{-1}\right)$. Similarly highest accumulation of TOC was observed in forest $\left(38.78 \mathrm{~g} \mathrm{~kg}^{-1}\right)$. About $43.19 \%$ and $37.40 \%$ of the TOC in forest land and grassland occurred as very labile $\mathrm{C}$ suggesting that the accumulated $\mathrm{C}$ could easily be lost following the land use change. Contrarily, the majority of TOC of cultivated and $\mathrm{jhum}$ land $(47.35 \%$ and $43.65 \%$ of TOC) was stabilized in the recalcitrant pool indicating more stable nature of the accumulated organic matter.
\end{abstract}

Keywords: SOC pools, land use types, hilly ecosystems, TOC

\section{Introduction}

Soil organic carbon (SOC) is reported as a sensitive indicator of soil quality and environmental sustainability (Lal, 2002). To sustain fertility and productivity of a soil, SOC is considered essential which can improve physical, chemical and biological properties of a soil (Pan et al., 2009), as well as it can be used for predicting climate change and effects on crop production (Kirschbaum, 2000). SOC stocks in soil consist of labile and non labile pool with varying residence time. Labile pool (active pool or light fraction pool) are the source of nutrients with most rapid turnover rates that influences the quality and productivity of soil, it is also available in a relatively small proportion because it is easily decomposed and extremely sensitive to environmental fluctuation. Such pool gets easily oxidized when disturbed due to any changes in land use practices (forest to agriculture land) and $\mathrm{CO}_{2}$ evolved during the process is contributing to the atmosphere and having an impact on global warming. Another type is the stable, resistant/recalcitrant pools with varying residence time (passive pool) is slowly decomposed by microbial activity so, it is not considered as a good parameter for soil quality but contributes in total organic carbon (TOC) stocks (Chan et al., 2001; Mandal et al., 2008). An effort to increase the reservoir through carbon sequestration will minimize global warming and also ensure global food security to a great extent (Lal, 2004) as, soil has twice the capacity to store C compared to the atmosphere (Davidson et al., 2000). The role of Forests has a great impact on the global biogeochemical cycles and in particular in the carbon cycle (Ravindranath and Ostwald, 2008). Larger parts of the global C stock are found to be stored in forest ecosystems. About $40 \%$ of the total SOC stock of the global soils lies in forest ecosystem and because of their higher organic matter content forest soils are known to be one of the major carbon sinks on earth (Dey, 2005). Depending on the changes happening to soil organic matter soils can act as sinks or as a source for carbon in the atmosphere.

Land use changes and management are widely recognized as the most important driving forces of global carbon cycles (Zhang et al., 2012), contribute 6\%-39\% of the growth in $\mathrm{CO}_{2}$ emissions (Brovkin et al., 2004) and have profound impacts on SOC which are estimated to be one of the second largest source of human- induced greenhouse gas emissions (1.5 $\mathrm{Pg} \mathrm{C/a)} \mathrm{after} \mathrm{fossil} \mathrm{fuel} \mathrm{combustion} \mathrm{(5.3} \mathrm{Pg} \mathrm{C/a)} \mathrm{(IPCC,} \mathrm{2007)}$ because, soils may provide an immediate sink for atmospheric $\mathrm{CO}_{2}$ with proper management. When there is land use changed and forests are cleared equilibrium between the 
rate of decomposition and rate of supply of organic matter is disturbed (Lal, 2004). So, Comprehensive knowledge of the effect of different land-use management on SOM content and composition is extremely important (Bruce et al., 1999). Poor soil management and the replacement of native forests by agricultural land may compromise soil health. The dramatic changes in vegetation cover are expected to modify soil $\mathrm{C}$ content and nutrient cycling, thus impacting environmental equilibrium and sustainability (Wilcke and Lilienfein, 2004). Conversion of natural forest to other form of landuse can aggravate soil erosion and lead to a reduction in soil organic content (Chen et al., 2001) and there is a change in the rates of accumulation, turnover and decomposition of SOC which make changes in SOC (Poeplau et al., 2011). There is very little information on soil carbon pools (carbon dynamics) in various land use types of hilly ecosystems of Manipur. Thus, an attempt was made to study the effect of land use types on various pools and stock of SOC in hilly ecosystems of Manipur, India.

\section{Materials and Methods}

\subsection{Description of the study area}

The study was conducted near Khamsom village, which is located in Senapati district, Manipur, India. Geographically, it lies between $25^{\circ} 18^{\prime} \mathrm{N}$ latitude and $94^{\circ} 15^{\prime} \mathrm{E}$ longitude. The altitude of the area is on the average $1441 \mathrm{~m} \mathrm{MSL}$. The study area is characterized by humid subtropical climate and the soil is moderately fertile with clay loam soil with little patches of clay and loam. The temperature ranges from a minimum of $2.4^{\circ} \mathrm{C}\left(36.3^{\circ} \mathrm{F}\right)$ to a maximum of $34.1^{\circ} \mathrm{C}\left(93.4^{\circ} \mathrm{F}\right)$ and the annual rainfall ranges from 670 to $1,450 \mathrm{~mm}$ (26.4$57.1 \mathrm{in}$ ). Four different well established (>10 years) land use systems were selected except for jhum (2 years) for the study. Those were i) Forest land (Natural mixed forest with dominant species of Quercus serrata, Castanopsis sp. and Alnus nepalensis), ii) Grassland (dominant species of Setaria viridis and Phalaris arundinacea), iii) Jhum and iv) Cultivated land (Rice, Oryza sativa).

\subsection{Soil sampling and sample preparation}

For each land use type 5 composite soil samples were collected from the depth of $0-20 \mathrm{~cm}$ during February-March, 2015. Composites were made in such a way by mixing three different soil samples collected from three locations of each surrounding areas. Approximately one kilogram of composite sample was taken from each sampling sites and put into plastic bags. The soil samples were air-dried at room temperature, crushed, homogenized, and passed through a 2 $\mathrm{mm}$ sieve before laboratory analysis. A total of 20 composite soil samples (five from each land use types) were collected for soil analysis. Undisturbed samples were also taken with a core sampler for bulk density determination.

\subsection{Soil analysis}

Soil $\mathrm{pH}$ was determined using glass electrode $\mathrm{pH}$ meter with the ratio between the soil water ratios of 1:2.5 (Jackson, 1973). Soil organic carbon (SOC) was determined by wet digestion method (Walkley and black, 1934), total organic carbon (TOC) by modified method of Nelson and Sommers (1982) as described by Majumder (2007) and available nitrogen (Av. N) nitrogen by titrimetrically following the the Kjeldhal method as described by Jackson (1973), available phosphorus (Av. P) by Bray's II method (Bray and Kurtz, 1945), available potassium (Av. K) by available ammonium acetate method (Jackson, 1973). The particle size distribution of the soil (sand, silt and clay) was determined by procedures suggested by Bouyoucos with the help of the hydrometer method (Bouyoucos, 1962). Bulk density was determined by core method. The SOC stocks were calculated as follows (Sharma et al., 2014).

SOC stocks $\left(\mathrm{mg} \mathrm{ha}^{-1}\right)=\mathrm{SOC} \times \rho \times \mathrm{d} \times 10,000$

Where SOC is the soil organic carbon measured in $\mathrm{g} \mathrm{g}^{-1} ; \rho$ is the soil bulk density $\left(\mathrm{g} \mathrm{cm}^{-3}\right), \mathrm{d}$ is the depth of soil layer $(\mathrm{m})$. The value of 10,000 indicates the stock for 1 ha of land.

\subsection{Pools of oxidisable organic carbon}

Different pools of $\mathrm{C}$ were estimated through a modified Walkley and Black method as described by Chan et al. (2001) using 5, 10 and $20 \mathrm{ml}$ of concentrated $\mathrm{H}_{2} \mathrm{SO}_{4}$ resulting three acid-aqueous solution ratios of $0.5: 1,1: 1$ and 2:1 (which corresponded respectively to $12.0 \mathrm{~N}, 18.0 \mathrm{~N}$ and $24.0 \mathrm{~N}$ of $\mathrm{H}_{2} \mathrm{SO}_{4}$ ). The amount of SOC were determined using 5, 10 and $20 \mathrm{ml}$ of concentrated $\mathrm{H}_{2} \mathrm{SO}_{4}$ when compared with TOC, allowed separation of TOC into the following four different pools of decreasing oxidizability.

\begin{tabular}{|c|c|}
\hline $\begin{array}{l}\text { Fraction } 1 \\
\text { (Very labile) }\end{array}$ & Organic $\mathrm{C}$ oxidisable under $12.0 \mathrm{~N} \mathrm{H}_{2} \mathrm{SO}_{4}$ \\
\hline $\begin{array}{l}\text { Fraction } 2 \\
\text { (Labile) }\end{array}$ & $\begin{array}{l}\text { Difference in SOC oxidisable under } 18.0 \mathrm{~N} \\
\text { and that under } 12.0 \mathrm{~N} \mathrm{H}_{2} \mathrm{SO}_{4}\end{array}$ \\
\hline $\begin{array}{l}\text { Fraction } 3 \\
\text { (Less labile) }\end{array}$ & $\begin{array}{l}\text { Difference in } \mathrm{SOC} \text { oxidisable under } 24.0 \mathrm{~N} \\
\text { and that under } 18.0 \mathrm{~N} \mathrm{H}_{2} \mathrm{SO}_{4} \text { (the } 24.0 \mathrm{~N} \\
\mathrm{H}_{2} \mathrm{SO}_{4} \text { is equivalent to the standard Walkley } \\
\text { and Black method) }\end{array}$ \\
\hline $\begin{array}{l}\text { Fraction } 4 \\
\text { (Recalcitrant) }\end{array}$ & $\begin{array}{l}\text { Residual organic } \mathrm{C} \text { after reaction with } 24.0 \\
\mathrm{~N} \mathrm{H}_{2} \mathrm{SO}_{4} \text { when compared with the TOC } \\
\text { (modified method of Nelson and Sommers, } \\
\text { 1982) (Majumder, 2007) }\end{array}$ \\
\hline
\end{tabular}

\subsection{Active and passive pools}

Fraction 1 and fraction 2 together is designated as 'active pool' of SOC because of their easy oxidizability (by weak 12.0 and $18.0 \mathrm{~N} \mathrm{H}_{2} \mathrm{SO}_{4}$ ). Again, summation of fraction 3 and fraction 4 together constitutes the 'passive pool' of SOC in the experimental soils.

\subsection{Statistical analysis}

The data obtained from the laboratory analysis were subjected to analyzed statistically following one way analysis (one way ANOVA) and means of the treatments were compared using 
the least significant difference (LSD) at 5\% probability level.

\section{Results and Discussion}

\subsection{Basic soil properties}

Soils under the four land-uses were clay loam to loam in texture and the content of soil separates (sand, silt and clay fractions) were significantly different (Table 1) where jhum land recorded highest content of sand (62.38\%) and lowest content of clay (20.97\%), whereas forest land recorded lowest sand content (40.29\%) and highest clay content (30.71\%). The bulk density (BD) of the cultivated land was recorded highest $\left(1.48 \mathrm{~g} / \mathrm{cm}^{-3}\right)$ and significantly higher than other land-uses, but the value of BD for the remaining land-uses was statistically at par with each other (Table 1). Our study of soil separates and BD were very similar to previous reports of Devi and Yadaba $(2009,2015)$. Based on the main effect of the land uses, the highest mean soil $\mathrm{pH}$ (Soil: $\left.\mathrm{H}_{2} \mathrm{O}:: 1: 2.5\right)$ was recorded in the soils of the cultivated land ( $\mathrm{pH}$ 5.97) and the lowest $(\mathrm{pH} 4.32)$ was observed in the soils of the forest land (Table 1 ). This could be attributed due to submergence of soil in rice field with water the $\mathrm{pH}$ of the soil increases. Low $\mathrm{pH}$ in forest and grassland were mostly attributed to the complex interaction of acid igneous parent materials, prone to water erosion induced leaching of bases under high intensity heavy rainfall in the undulating topography with steep slopes. In jhum removing of tree canopy coverage followed by burning surface covering vegetations, thereby exposing the barren surface of high runoff induced erosion in the sloppy land and subsequently loss of bases along with top fertile soils result in low $\mathrm{pH}$ (Singh et al., 1992). Soil organic carbon (SOC) content of forest land recorded highest $\left(23.68 \mathrm{~g} \mathrm{~kg}^{-1}\right)$ followed by grassland which were statistically at par with each other and the lowest among them was cultivated rice land $\left(13.13 \mathrm{~g} \mathrm{~kg}^{-1}\right)$. Thus, forest land and grassland systems had significantly higher concentration

Table 1: Basic soil properties in forest, grassland, jhum and cultivated land

\begin{tabular}{lcccc}
\hline Soil properties & $\begin{array}{c}\text { Forest } \\
\text { land }\end{array}$ & Grassland & Jhum & $\begin{array}{c}\text { Cultivated } \\
\text { land }\end{array}$ \\
\hline $\begin{array}{l}\text { Bulk density (g } \\
\text { cm }^{-3} \text { ) }\end{array}$ & $1.35^{\mathrm{b}}$ & $1.38^{\mathrm{b}}$ & $1.29^{\mathrm{b}}$ & $1.48^{\mathrm{a}}$ \\
Sand (\%) & $40.29^{\mathrm{d}}$ & $53.64^{\mathrm{b}}$ & $62.38^{\mathrm{a}}$ & $45.28^{\mathrm{c}}$ \\
Silt (\%) & $29.00^{\mathrm{b}}$ & $17.14^{\mathrm{c}}$ & $16.65^{\mathrm{d}}$ & $36.50^{\mathrm{a}}$ \\
Clay (\%) & $30.71^{\mathrm{a}}$ & $29.22^{\mathrm{a}}$ & $20.97^{\mathrm{c}}$ & $18.22^{\mathrm{b}}$ \\
pH (H O) & $4.32^{\mathrm{b}}$ & $4.43^{\mathrm{b}}$ & $4.36^{\mathrm{b}}$ & $5.97^{\mathrm{a}}$ \\
SOC (g kg $\left.{ }^{-1}\right)$ & $23.68^{\mathrm{a}}$ & $21.80^{\mathrm{ab}}$ & $19.08^{\mathrm{b}}$ & $13.13^{\mathrm{c}}$ \\
Av. N (kg ha $\left.{ }^{-1}\right)$ & $250.3^{\mathrm{a}}$ & $208.8^{\mathrm{b}}$ & $200.6^{\mathrm{b}}$ & $176.4^{\mathrm{c}}$ \\
Av. P $\left(\mathrm{kg} \mathrm{ha}^{-1}\right)$ & $16.86^{\mathrm{a}}$ & $15.59^{\mathrm{a}}$ & $9.41^{\mathrm{c}}$ & $12.61^{\mathrm{b}}$ \\
Av. K (kg ha-1) & $196.3^{\mathrm{c}}$ & $134.3^{\mathrm{d}}$ & $272.2^{\mathrm{b}}$ & $371.8^{\mathrm{a}}$ \\
\hline
\end{tabular}

Mean value in a row followed by same letter are not significantly different at $p<0.05$ of SOC than the cultivated land use (Table 1). Since for accumulation of SOC in soil, clay content is a very important factor (Christensen, 1992) and in the present research, clay per cent of both forest and grassland are significantly higher than jhum and cultivated land. A similar finding by Franzluebbers (2010) reveals that SOC was found to be higher under pasture than croplands and was not different from that under forest in the southeastern United State of America. In cultivated rice, low SOC is due to repeated cultivation / disturbance (puddling) over the year (Majumdar et al., 2007), erosion losses of soil and almost complete removal of crop residues from the cultivated fields for various reasons. With the same reason cited above, the available $\mathrm{N}$ and available $\mathrm{P}$ of forest land were significantly higher than other land uses. But available $\mathrm{K}$ in soil was recorded highest in cultivated land followed by jhum, which may be attributed due to regular supplementation of potassic fertilizers under rice cultivation and in jhum which is freshly burned (1-2 year), ashes were added to the soil which increase the $\mathrm{pH}$, thereby increased the availability of nutrients in the soils, especially in the surface (Tanaka et al., 2004) and the values are comparable with the forest and grassland.

\subsection{Total organic carbon and its fraction}

Highest accumulation of TOC was observed in case of forest $\left(38.78 \mathrm{~g} \mathrm{~kg}^{-1}\right)$, and was statistically at par with grassland $(36.63$ $\mathrm{g} \mathrm{kg}^{-1}$ ). It was found that TOC of Jhum land (33.86 $\mathrm{g} \mathrm{kg}^{-1}$ ) also was statistically at par with the grassland, while cultivated land showed significantly lowest value (Table 2 ). Which may be attributed due to residue additions in forest and permanent grassland land-use systems can augment soil aggregation and, concomitantly, soil C content (Bossuyt et al., 2002). In cultivated land, due to disturbance in soil the loss of $C$ takes place (Beare et al., 1994). It was again observed that highest SOC stock of forest ( $\left.63.47 \mathrm{mg} \mathrm{ha}^{-1}\right)$ was statistically at par with grassland ( $\left.60.33 \mathrm{mg} \mathrm{ha}^{-1}\right)$ and such stock of cultivated land (38.69 $\mathrm{Mg} \mathrm{ha}^{-1}$ ) was lowest (Figure 1) and among the different land-uses taken its stock follows the order: forest> grassland $>$ jhum $>$ cultivated land in decreasing order, which

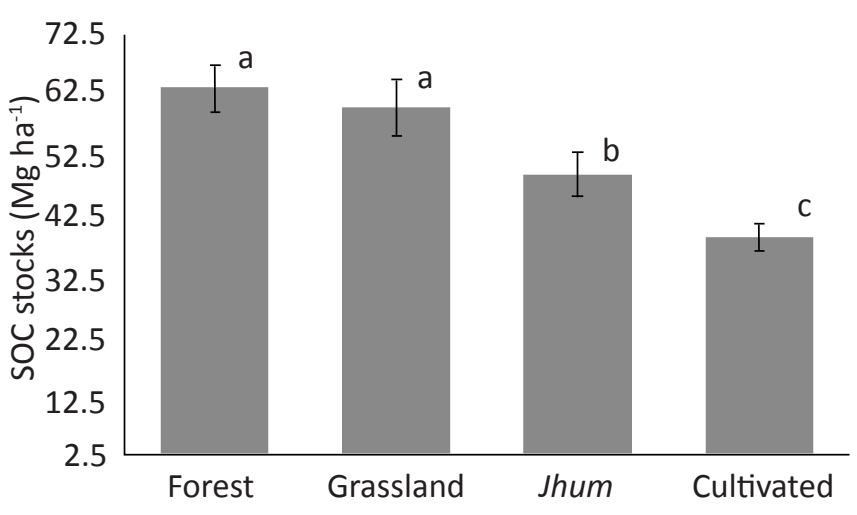

Figure 1: Soil organic carbon stocks $\left(\mathrm{mg} \mathrm{ha}^{-1}\right)$. Bars labeled with the same letter are not singnificantly different at $p<0.005$ (LSD 9.32). Line bars indicate standard error mean. 
Table 2: Concentration of organic $\mathrm{C}$ fractions $\left(\mathrm{g} \mathrm{kg}^{-1}\right)$ of varying oxidizability in soils of forest, grassland, jhum and cultivated landuse systems in the Senapati district of Manipur

\begin{tabular}{lccccccc}
\hline Landuses & $\begin{array}{c}\text { Fraction 1 } \\
\text { (V. labile) }\end{array}$ & $\begin{array}{c}\text { Fraction 2 } \\
\text { (labile) }\end{array}$ & $\begin{array}{c}\text { Fraction 3 } \\
\text { (less labile) }\end{array}$ & $\begin{array}{c}\text { Fraction 4 } \\
\text { (recalcitrant) }\end{array}$ & Active pool & Passive pool & TOC $\left(\mathrm{g} \mathrm{kg}^{-1}\right)$ \\
\hline Forest & $16.75^{\mathrm{a}}(2.16)$ & $6.30^{\mathrm{a}}(0.76)$ & $0.63^{\mathrm{c}}(0.13)$ & $15.10^{\mathrm{a}}(0.19)$ & $23.05^{\mathrm{a}}(1.83)$ & $15.73^{\mathrm{b}}(0.28)$ & $38.78^{\mathrm{a}}(1.97)$ \\
Grassland & $13.70^{\mathrm{a}}(1.18)$ & $5.40^{\mathrm{a}}(0.74)$ & $2.70^{\mathrm{a}}(0.35)$ & $14.83^{\mathrm{a}}(0.57)$ & $19.10^{\mathrm{b}}(1.41)$ & $17.53^{\mathrm{a}}(0.66)$ & $36.63^{\mathrm{ab}}(1.25)$ \\
Jhum & $8.80^{\mathrm{b}}(0.35)$ & $7.75^{\mathrm{a}}(1.40)$ & $2.53^{\mathrm{a}}(0.10)$ & $14.78^{\mathrm{a}}(0.52)$ & $16.55^{\mathrm{b}}(1.69)$ & $17.31^{\mathrm{a}}(0.57)$ & $33.86^{\mathrm{b}}(1.13)$ \\
Rice & $5.63^{\mathrm{c}}(0.51)$ & $5.85^{\mathrm{a}}(0.64)$ & $1.65^{\mathrm{b}}(0.31)$ & $11.81^{\mathrm{b}}(0.32)$ & $11.48^{\mathrm{c}}(0.70)$ & $13.46^{\mathrm{c}}(0.30)$ & $24.94^{\mathrm{c}}(0.54)$ \\
LSD (0.05) & 3.24 & $\mathrm{NS}$ & 0.65 & 1.18 & 3.42 & 1.20 & 3.30 \\
\hline
\end{tabular}

Mean values in a column followed by same letter are not significantly different at $p<0.05$; Values in parenthesis indicate standard error of mean; NS: Non-significant

could be due to the above reason. In Indo-Gangetic plains in India, Abrol et al. (2000) also found the declining of carbon stocks with year in rice-based cropping system.

Results obtained from the investigation of different land-use system on soil oxidisable organic carbon fractions revealed that soils under forest had recorded significantly highest concentration (16.75 $\mathrm{g} \mathrm{kg}^{-1}$ ) of very labile C (fraction 1) which was statistically at par with grassland $\left(13.71 \mathrm{~g} \mathrm{~kg}^{-1}\right)$. It was observed that in forest land, fraction 1 (very labile pool) contributed $43.19 \%$ of TOC. While the contribution of fraction 1 (very labile) towards TOC for grassland, jhum land and cultivated rice land was $37.40 \%, 25.99 \%$ and $22.57 \%$ respectively (Figure 2 ) although there was variation in TOC content in such land uses.

There was no significant variation in labile $C$ (fraction 2) content of various land use types where forest land recorded highest and that of grassland recorded lowest. However, it

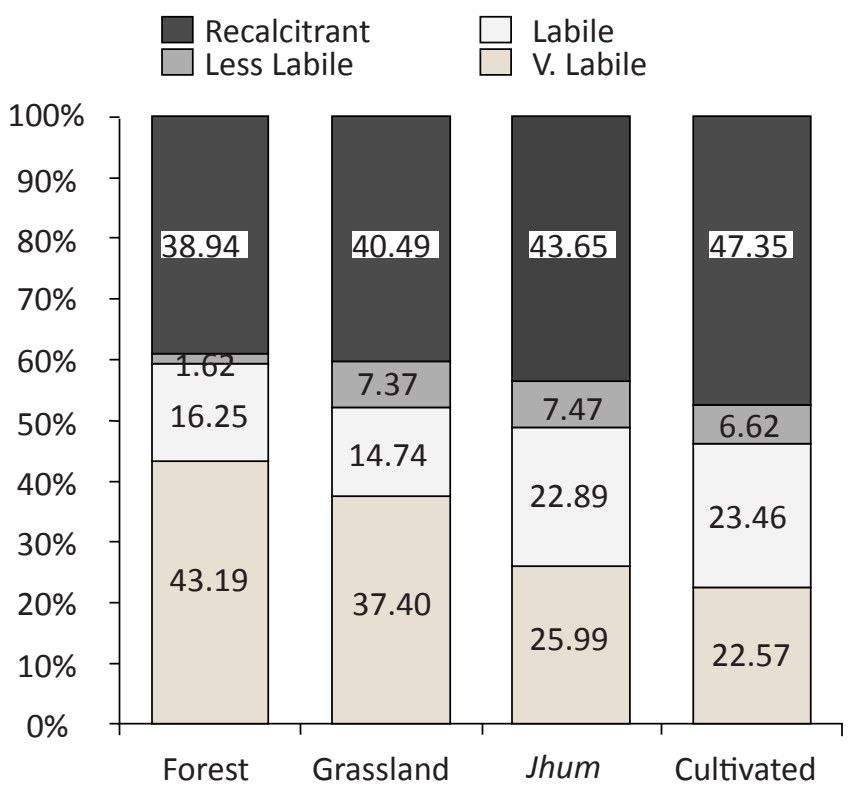

Figure 2: Per cent contribution of various pools of carbon of varying labillity towards total organic carbon (TOC) in different landuse systems was found that in cultivated rice land, fraction 2 (labile pool) contributed $23.46 \%$ of TOC. While the contribution of fraction 2 (labile pool) towards TOC for forestland, grassland and jhum land was $16.25 \%, 14.74 \%$ and $22.89 \%$ respectively (Figure 2).

Among the studied land-use systems, grassland $(2.70 \mathrm{~g}$ $\mathrm{kg}^{-1}$ ) recorded highest less labile C (fraction 3) which was statistically at par with the jhum $\left(2.53 \mathrm{~g} \mathrm{~kg}^{-1}\right)$ land and that of forest land recorded lowest content of less labile C ( 0.63 $\left.\mathrm{g} \mathrm{kg}^{-1}\right)$. When contribution of this less labile fraction towards TOC was calculated it was observed that in jhum land its contribution was $7.47 \%$ and that of forestland, grassland and cultivated rice land was $1.62 \%, 7.37 \%$ and $6.62 \%$ respectively (Figure 2).

The highest and lowest concentration of recalcitrant $C$ (fraction 4) occurred in soils of forest land $\left(15.10 \mathrm{~g} \mathrm{~kg}^{-1}\right)$ and cultivated rice land $\left(11.81 \mathrm{~g} \mathrm{~kg}^{-1}\right)$ respectively (Table 2$)$. When contribution of this less recalcitrant C (fraction 4) towards TOC was calculated it was observed that in cultivated rice land, its contribution was $47.35 \%$ and that of forestland, grassland and jhum land was $38.94 \%, 40.49 \%$ and $43.65 \%$ of TOC respectively (Figure 2 ).

The active $C$ pools of forest land was recorded highest $\left(23.05 \mathrm{~g} \mathrm{~kg}^{-1}\right)$ followed by: grassland $>$ jhum $>$ cultivated land in decreasing order (Table 2). It was observed that contribution of active C pool of forestland, grassland, jhum land and cultivated rice land towards TOC was 59.44\%, 52.14\%, 48.88\% and $46.03 \%$ respectively. The highest passive $C$ pools (fraction 3 + fraction 4) was recorded under grassland $\left(17.53 \mathrm{~g} \mathrm{~kg}^{-1}\right)$ followed by jhum (17.31 $\left.\mathrm{g} \mathrm{kg}^{-1}\right)>$ forest land $\left(15.73 \mathrm{~g} \mathrm{~kg}^{-1}\right)>$ cultivated rice land $\left(13.46 \mathrm{~g} \mathrm{~kg}^{-1}\right)$ in decreasing order (Table 2). However, the passive pools of cultivated land contributed $53.97 \%$ of the TOC and that of jhum land, grassland and forestland contributed $51.12 \%, 47.86 \%$ and $40.56 \%$ of TOC respectively. The clay content of soil can affect the change of active carbon pools and stabilization of passive carbon pools (Hassink, 1994). In the recent findings the clay content of the soil also follows the same order. The high values of labile $C$ in forest can also be attributed to the constant supply of easily decomposable leaf litter throughout the year. Due to the high 
altitude low temperature prevalent in the ecosystem may result in reduced or slower rate of residue decomposition and the absence of annual tillage added higher carbon values (Haynes, 2005). A similar results was obtained by Kalambukattu et al. (2013), in which TOC and labile carbon in 0-15 cm soil depth were observed in undisturbed oak forest of central Himalayan region. On the other hand lower values of labile C of TOC in the cultivated land can be associated with aggregate disruption and greater organic matter oxidation in conventional agricultural systems based on ploughing and harrowing (Bayer et al., 2006).

\section{Conclusion}

Forest and grassland systems showed higher concentrations and greater soil organic carbon stocks than cultivated rice land and jhum land. The majority of soil organic carbon of forest land and grassland was in an easily oxidisable labile form, suggesting that the accumulated carbon could be easily lost following the land use change. Conversely, preponderance of less labile or recalcitrant forms in cultivated rice system indicated more stable nature of the accumulated soil organic carbon.

\section{References}

Abrol, I.P., Bronson, K.F., Duxbury, J.M., Gupta, R.K., 2000. Long-term soil fertility experiments in rice-wheat cropping systems. Rice-wheat consortium paper series 6. New Delhi, 171.

Bayer, C., Martin-Neto, L., Mielniczuk, J., Pavinato, A., Dieckow, J., 2006. Carbon sequestration in two Brazilian Cerrado soils under no-till. Soil and Tillage Research 86, 237-245.

Beare, M.H., Cabrera, M.L., Hendrix, P.F., Coleman, D.C., 1994. Aggregate protected and unprotected organic matter pools in conventional- and no-tillage soils. Soil Science Society of America Journal 58, 787-795.

Bossuyt, B., Heyn, M., Hermy, M., 2002. Seed bank and vegetation composition of forest stands of varying age in central Belgium: consequences for regeneration of ancient forest vegetation. Plant Ecology 162, 33-48.

Bouyoucos, G.J., 1962. Hydrometer method improved for particle size analysis of soil. Agronomy Journal 54, 464-465.

Bray, R.H., Kurtz, L.T., 1945. Determination of total, organic and available forms of phosphorus in soils. Soil Science 59, 39-45.

Brovkin, V., Stich, S., von Bloh, W., Claussen, M., Bauer, E., Cramer, W., 2004. Role of land cover changes for atmospheric $\mathrm{CO}_{2}$ increase and climate change during the last 150 years. Global Change Biology 10, 1253-1266.

Bruce, J.P., Frome, M., Haites, E., Joanne, H., Lal, R., Faustian, K., 1999. Carbon sequestration in soils. Journal of Soil and Water Conservation 54, 382-386.

Chan, K.Y., Bowman, A., Oates, A., 2001. Oxidizable organic carbon fractions and soil quality changes in an oxic paleustalf under different pasture leys. Soil Science $166,61-67$.

Chen, G., Gan, L., Wang, S., 2001. A comparative study on the microbial characteristics of soils under different land use conditions from karst area of Southwest China. Chinese Journal of Geochemistry 20(1), 52-58.

Christensen, B.T., 1992. Physical fractionation of soil and organic matter in primary particle size and density separates. Advances in soil science. Springer New York, 1-190.

Davidson, E.A., Trumbore, S.E., Amundson, R., 2000. Biogeochemistry: soil warming and organic carbon content. Nature 408, 789-790.

Devi, N.B., Yadava, P.S., 2009. Emission of $\mathrm{CO}_{2}$ from the soil and immobilization of carbon in microbes in a subtropical mixed oak forest ecosystem, Manipur, Northeast India. Current Science 96(12), 1627-1630.

Devi, N.B., Yadava, P.S., 2015. Abiotic Factors Influences Soil Carbon Dioxide Flux in the Sub-Tropical Forests, Manipur, NE India. International journal of scientific research 4(5), 2277-8179.

Dey, S.K., 2005. A preliminary estimation of carbon stock sequestrated through rubber (Hevea brasiliensis) plantation in North Eastern regional of India. Indian Forester 131(11), 1429-1435.

Franzluebbers, A.J., 2010. Soil organic carbon in managed pastures of the southeastern United States of America. Grassland Carbon Sequestration: Management, Policy and Economics. Integrated Crop Management 11, 163-175.

Hassink, J., 1994. Effects of soil texture and grassland management on soil organic $\mathrm{C}$ and $\mathrm{N}$ and rates of $\mathrm{C}$ and $\mathrm{N}$ mineralization. Soil Biology and Biochemistry 9, 1221-1231.

Haynes, R.J., 2005. Labile organic matter fractions as central components of the quality of agricultural soils: An overview. Advances in Agronomy 85, 221-268.

IPCC, 2007. Climate Change 2007: Mitigation of Climate Change. Cambridge University Press, Cambridge. Available from: http://www.ipcc.ch/publications_and_ data/ar4/wg3/en/content s.html (verified 3 January 2012).

Jackson, M.L., 1973. Soil Chemical Analysis. Prentice-Hall India Pvt Ltd., New Delhi, 495.

Kalambukattu, J.G., Singh, R., Patra, A.K., Arun kumar, K., 2013. Soil carbon pools and carbon management index under different land use systems in the Central Himalayan region. Soil and plant science 63(3), 200-205.

Kirschbaum, M.U.F., 2000. Will changes in soil organic carbon act as a positive or negative feed-back on global warming? Biogeochemistry 48, 21-51.

Lal, R., 2002. Soil carbon dynamics in cropland and rangeland. Environmental Pollution 116(3), 353-362. 
Lal, R., 2004. Soil carbon sequestration impacts on global climate change and food security. Science 304, 16231627.

Majumder, B., 2007. Soil organic carbon pools and biomass productivity under agro-ecosystem of sub-tropical India. Ph.D. thesis, Jadavpur University, Environmental Engineering Division, Department of Civil Engineering, Kolkata, 152.

Majumder, B., Mandal, B., Bandyopadhyay, P.K., Chaudhury, J., 2007. Soil organic carbon pools and productivity relationships for a 34 year old rice-wheat-jute agroecosystem under different fertilizer treatments. Plant Soil 297, 53-67.

Mandal, B., Majumder, B., Adhya, T.K., Bandyopadhyay, P.K., Gangopadhyay, A., Sarkar, D., Kundu, M.C., Choudhury, S.G., Hazra, G.C., Kundu, S., Samantaray, R.N., Misra, A.K., 2008. Potential of double-cropped rice ecology to conserve organic carbon under subtropical climate. Global Change Biology 14, 2139-2151.

Nelson, D.W., Sommers, L.E., 1982. Total carbon, organic carbon and organic matter. In: Page, A.L., Miller, R.H., Keeney, D.R. (eds.), Methods of Soil Analysis, Part 2. Agron. Monog. No 12, $2^{\text {nd }}$ ed. ASA and SSSA, Madison, WI. 101-129.

Pan, G., Zhou, P., Li, Z., Pete, S., Li, L., Qiu, D., Zhang, X., Xu, X., Shen, S., Chen, X., 2009. Combined inorganic/organic fertilization enhances $\mathrm{N}$ efficiency and increases rice productivity through organic carbon accumulation in a rice paddy from the Tai Lake region, China. Agriculture Ecosystems and Environment 131, 274-280.

Poeplau, C., Don, A., Vesterdal, L., Leifeld, J., Van Wesemael, B.A.S., Schumacher, J., Gensior, A., 2011. Temporal dynamics of soil organic carbon after land-use change in the temperate zone-carbon response functions as a model approach. Global Change Biology 17, 2415-2427.

Ravindranath, N.H., Ostwald, M., 2008. Carbon Inventory Methods for National Greenhouse Gas Inventory. Carbon Inventory Methods Handbook for Greenhouse Gas Inventory, Carbon Mitigation and Roundwood Production Projects, 217-235.

Sharma, V., Hussain, S., Sharma, K.R., Arya, V.M., 2014. Labile carbon pools and soil organic carbon stocks in the foothill Himalayas under different land use systems. Geoderma 232-234, 81-87.

Singh, B.P., Das, M., Prasad, R.N., 1992. Effect of different landuse systems on nutrient availability in hilly terrains of Meghalaya (India). Proc. Inter. Symp. On Nutrient Management for sustained Productivity, Vol.II, 60-62.

Tanaka, S., Kendawang, J.J., Yoshida, N., Shibata, K., Jee, A., Tanaka, K., Ninomiya, I., Sakurai, K., 2004. Effects of Shifting Cultivation on Soil Ecosystems in Sarawak, Malaysia II. Changes in soil chemical properties and runoff water at Balai Ringin and Sabal experimental sites. Soil Science and Plant Nutrition 50(5), 689-699.

Walkley, A., Black, I.A., 1934. An examination of the Degtjareff method for getermining soil organic matter, and a proposed modification of the chromic acid titration method. Soil Science 37(1), 29-38.

Wilcke, W., Lilienfein, J., 2004. Soil ${ }^{13} \mathrm{C}$ natural abundance under native and managed vegetation in Brazil. Soil Science Society of America Journal 68, 827-832.

Zhang, L., Xie, Z., Zhao, R.F., Wang, Y.J., 2012. The impact of land use change on soil organic carbon and labile organic carbon stocks in the Longzhong region of Loess Plateau. Journal of Arid Land 4(3), 241-250. 